\title{
Environmental friendly maize (Zea mays L.) production on chernozem soil in Hungary
}

\author{
Peter Pepó \\ Institute of Crop Sciences, Agronomy Faculty, University of Debrecen, \\ H-4032 Debrecen, Böszörményi str. 138. e-mail: pepopeter@agr.unideb.hu
}

Keywords: maize, abiotic stress, cropyear, yield

\section{SUMMARY}

We have been studied the effects of crop-rotation, fertilization and irrigation on the yields of maize in different cropyears characterized by different water supply (2007 year=dry; 2008 year=optimum) on chernozem soil. Our scientific results proved that in water stress cropyear (2007) the maximum yields of maize were $4316 \mathrm{~kg} \mathrm{ha}^{-1}$ (monoculture), $7706 \mathrm{~kg} \mathrm{ha}^{-1}$ (biculture), $7998 \mathrm{~kg} \mathrm{ha}^{-1}$ (triculture) in non irrigated circumstances and $8586 \mathrm{~kg} \mathrm{ha}^{-1}, 10970 \mathrm{~kg} \mathrm{ha}^{-1}, 10679 \mathrm{~kg} \mathrm{ha}^{-1}$ in irrigated treatment, respectively. In dry cropyear (2007) the yield-surpluses of irrigation were $4270 \mathrm{~kg} \mathrm{ha}^{-1}$ (mono), $3264 \mathrm{~kg} \mathrm{ha}^{-1}$ (bi), $2681 \mathrm{~kg} \mathrm{ha}^{-1}$ (tri), respectively. In optimum water supply cropyear (2008) the maximum yields of maize were $13729-13787$ (mono), 14 137-14 $152 \mathrm{~kg} \mathrm{ha}^{-1}$ (bi), 13 987-14 $180 \mathrm{~kg} \mathrm{ha}^{-1}$ (tri) so there was no crop-rotation effect. In water stress cropyear (2007) fertilization caused yield depression in non irrigated treatment (control $=2685 \mathrm{~kg} \mathrm{ha}^{-1}$; $\left.N_{240}+P K=2487 \mathrm{~kg} \mathrm{ha}^{-1}\right)$. Our scientific results proved that the effects of abiotic stress could be strongly reduced by using the optimum crop models in maize production. We obtained 8,6-11,0 t ha $a^{-1}$ maximum yields of maize in water stress cropyear and 13,7-14,2 $t$ ha in $^{-1}$ optimum cropyear on chernozem soil with using appropriate agrotechnical elements.

\section{INTRODUCTION}

Maize is an important cereal crop both in Hungary and in the World. In Hungary, maize is produced on 1.11.2 million ha (25\% of the arable land) and the yields range between 4 and $7 \mathrm{tha}^{-1}$ depending on the cropyear and the applied agrotechnical methods. The yield of maize is significantly changes on farm and plot level as well, which shows the high sensitivity of the plant for ecologic and agrotechnical factors (PEPÓ et al. 2006). Fertilization, genetics, crop protection, plant density and irrigation as production technology factors play important role in the determination of maize yields (GYÖRFFY 1976, NAGY 1996, SÁRVÁRI and SZABÓ 1998, PEPÓ 2001).

To some extent, the negative influence of climatic factors can be reduced by appropriate hybrid selection (SÁRVÁRI 1995, PEPÓ et al. 2007) and by appropriate agrotechnical management. Nutrient and water supply are determining agrotechnical factors. Maize needs harmonized NPK fertilization; however, out of macroelements nitrogen has significant importance (BERZSENYI 1993, LIANG and MAC KENZIE 1994, KOVAČEVIC et al. 2006, IZSÁKI 2007). In dry years the role of irrigation is especially significant in ensuring high yields of maize (RUZSÁNYI 1990, PEPÓ et al. 2008).

\section{MATERIALS AND METHODS}

The long-term experiment was set up in 1983 on chernozem soil in the Hajdúság (Eastern Hungary) by Prof. László Ruzsányi. The multifactorial experiment has been managed by Prof. Péter Pepó since 2004. Regarding the physical characteristics of the soil, the area can be classified as loam and has a nearly neutral $\mathrm{pH}$ value $\left(\mathrm{pH}_{\mathrm{KCl}}=6.46\right)$. It has a medium-level humus content $(2.8 \%)$ and a humus depth of about $80 \mathrm{~cm}$. Its supply of phosphorous is medium and its supply of potassium can be considered good. The structure of the multifactorial experiment is as follows:

- crop rotation: monoculture (maize), biculture (wheat-maize), triculture (peas-wheat-maize)

- fertilization: control, one-, two-, three- and fourfold amounts of the basic dosage of $\mathrm{N}=60 \mathrm{~kg} \mathrm{ha}^{-1}$, $\mathrm{P}_{2} \mathrm{O}_{5}=45 \mathrm{~kg} \mathrm{ha}^{-1}, \mathrm{~K}_{2} \mathrm{O}=45 \mathrm{~kg} \mathrm{ha}^{-1}$

- irrigation: not irrigated and irrigated

During the vegetation period of 2007, irrigation was applied $4 \times 50 \mathrm{~mm}(200 \mathrm{~mm})$ in the irrigated treatment (between early May and late June). In 2008 year we did not applied irrigation. Against Diabrotica virgifera in 2007 year we used soil desinfection in monoculture (Force 1,5 G $14 \mathrm{~kg} \mathrm{ha}^{-1}$ ) and sprayed in mono-, bi- and triculture (17 July, Karate Zeon 0,3 $1 \mathrm{ha}^{-1}$ ) and in 2008 year we applied soil desinfection (Force 1,5 G $14 \mathrm{~kg} \mathrm{ha}^{-1}$ ) in mono- and biculture but there was no spraying in the vegetation period. We applied $60.000 \mathrm{ha}^{-1}$ plant density in 2007 and 2008 years in all crop rotations. The other agrotechnical elements met the requirements set by modern maize production. The hybrid Reseda (PR 37 M 81) was used in our long-term experiments.

Table 1 contains the 30 year average of the most important meteorological parameters (rainfall, temperature) and these parameters in the cropyears of 2007 and 2008. 
Meteorological data of vegetation period

\begin{tabular}{|r|r|r|r|r|r|r|r|}
\hline & April & May & June & July & August & September & Average \\
\hline & & & & & & & Total \\
\hline Temperature ${ }^{\circ} \mathrm{C}$ & & & & & & & \\
\hline 30 year average & 10,7 & 15,8 & 18,7 & 20,3 & 19,6 & 15,8 & 16,8 \\
\hline 2007. year & 12,6 & 18,4 & 22,2 & 23,3 & 22,3 & 14,0 & 18,8 \\
\hline 2008. year & 11,4 & 16,8 & 20,6 & 20,4 & 20,6 & 14,8 & 17,4 \\
\hline Rainfall (mm) & & & & & & & \\
\hline 30 year average & 42,4 & 58,8 & 79,5 & 65,7 & 60,7 & 38,0 & 345,1 \\
\hline 2007. year & 3,6 & 54,0 & 22,8 & 39,7 & 77,6 & 86,1 & 283,8 \\
\hline 2008. year & 74,9 & 47,6 & 140,1 & 144,9 & 34,2 & 42,2 & 483,9 \\
\hline
\end{tabular}

\section{RESULTS AND DISCUSSION}

For the production of the huge vegetative and generative mass maize requires sufficient amount of nutrients and water during the cropyear. The nutrient and water uptake of maize is influenced by several ecological (weather, soil), biological (hybrid) and agrotechnical (crop rotation, soil cultivation, fertilization, crop density, irrigation) factors.

In our long-term experiment the yields of maize were primarily determined by abiotic stress (meteorological factors) (Table 2). In the dry cropyear of 2007, in natural circumstances (if no irrigation was applied) the yields of maize ranged between $2685-4316 \mathrm{~kg} \mathrm{ha}^{-1}$ yields in monoculture, 6258-7706 kg ha ${ }^{-1}$ in biculture and 6716$7998 \mathrm{~kg} \mathrm{ha}^{-1}$ in triculture. In years with favourable climatic conditions the yields difference among the different crop rotation systems was minimal and not significant. In 2008 no irrigation was necessary. The yields of maize ranged between $9154-13787 \mathrm{~kg} \mathrm{ha}^{-1}$ (non-irrigated) and 8830-13 $729 \mathrm{~kg} \mathrm{ha}^{-1}$ (irrigated) in monoculture, 11613 $14137 \mathrm{~kg} \mathrm{ha}^{-1}$ (non-irrigated) and 12 314-14 152 kg ha-1 (irrigated) in biculture, and 11 291-13 $987 \mathrm{~kg} \mathrm{ha}^{-1}$ (non-irrigated) and $10874-14180 \mathrm{~kg} \mathrm{ha}^{-1}$ (irrigated) in triculture.

In dry cropyear (2007) the yield increase generated by irrigation was modified partly by crop rotation and partly by nutrient supplementation. The yield-increasing effect of irrigation only prevailed if sufficient nutrient supply was provided, i.e. there is close correlation between the nutrient and water supply. In the control treatment in 2007 the yield surpluses of irrigation ranged between $1486-2525 \mathrm{~kg} \mathrm{ha}^{-1}$, in the optimal fertilization treatment it ranged between 2681-4270 kg ha ${ }^{-1}$. The highest yield increases were obtained in the most unfavourable monoculture system concerning the water management of the soil, while in crop rotation systems involving low water consuming crops the yield-increasing effect of irrigation was moderate (in biculture 2155$3264 \mathrm{~kg} \mathrm{ha}^{-1}$, in triculture $1436-2681 \mathrm{~kg} \mathrm{ha}^{-1}$ as results of irrigation).

Table 2.

Effects of cropyear and agrotechnical elements on the yields of maize (Debrecen, 2007-2008, chernozem soil)

\begin{tabular}{|c|r|r|r|r|r|r|}
\hline \multicolumn{7}{|c|}{ Debrecen, 2007-2008, chernozem soil) } \\
& \multicolumn{2}{|c|}{ Monoculture } & \multicolumn{2}{c|}{ Biculture } & \multicolumn{2}{c|}{ Triculture } \\
& 2007 & 2008 & 2007 & 2008 & 2007 & 2008 \\
\hline \hline Non irrigated & & & & & & \\
$\varnothing$ & 2685 & 9154 & 6258 & 11613 & 6716 & 11291 \\
$\mathrm{~N}_{60}+\mathrm{PK}$ & 3465 & 11057 & 7012 & 13740 & 7998 & 13323 \\
$\mathrm{~N}_{120}+\mathrm{PK}$ & 4316 & 13494 & 7706 & 14137 & 7062 & 13987 \\
$\mathrm{~N}_{180}+\mathrm{PK}$ & 2691 & 13787 & 7096 & 14003 & 6802 & 13351 \\
$\mathrm{~N}_{240}+\mathrm{PK}$ & 2487 & 13058 & 6829 & 13688 & 6630 & 13423 \\
Irrigated & & & & & & \\
$\varnothing$ & 5210 & 8830 & 8413 & 12314 & 8152 & 10874 \\
$\mathrm{~N}_{60}+\mathrm{PK}$ & 7105 & 10827 & 9735 & 13709 & 10358 & 13576 \\
$\mathrm{~N}_{120}+\mathrm{PK}$ & 8449 & 12964 & 10970 & 14152 & 10679 & 13857 \\
$\mathrm{~N}_{180}+\mathrm{PK}$ & 8586 & 13729 & 9965 & 13859 & 9880 & 14180 \\
$\mathrm{~N}_{240}+\mathrm{PK}$ & 8007 & 13372 & 9189 & 13600 & 9918 & 13245 \\
\hline LSD $_{5 \%}$ & \multicolumn{6}{|c|}{825} \\
\hline
\end{tabular}

The appropriate nutrient supply of maize is highly important in the decreasing of unfavourable abiotic stress (weather) and in the realizing of yield increasing effect of optimal water supply. Our results prove that in dry year (2007) the yield increasing effect of fertilization was lower than in humid year (2008). In dry year compared to the control treatment fertilization caused only moderate yield increase $\left(1282-1631 \mathrm{~kg} \mathrm{ha}^{-1}\right.$ according to the crop rotation system) in non-irrigated circumstances. In treatments where irrigation was applied the yield increasing effect of fertilization was significantly higher, almost twice compared with the non-irrigated treatment. In humid year (2008) the yield increase generated by fertilization was determined by the crop rotation system. Significantly high yield increase was obtained in monoculture (4633-4899 kg ha ${ }^{-1}$ yield increase 
compared with the control), but the values were good in biculture (1838-2524 kg ha-1 yield increase) and triculture (2696-3306 kg ha-1 yield increase) as well. The yield surpluses were especially high in humid years, considering the control yields (8.8-9.1 t ha ${ }^{-1}$ in monoculture; 11.6-12.3 tha $\mathrm{th}^{-1}$ in biculture; $10.9-11.3 \mathrm{t} \mathrm{ha}^{-1}$ in triculture) because of the excellent nutrient husbandry of the chernozem soil in the research field.

In dry year (2007) in non-irrigated circumstances the fertilization dose exceeding the agronomic optimum of maize $\left(\mathrm{N}_{240}+\mathrm{PK}\right)$ decreased the yields compared to the optimal treatment, furthermore, in extreme water conditions the yields were lower than in the control treatment (control treatment in monoculture: $2685 \mathrm{~kg} \mathrm{ha}^{-1}$, in the $\mathrm{N}_{240}+\mathrm{PK}$ treatment: $2487 \mathrm{~kg} \mathrm{ha}^{-1}$, in triculture were: $6716 \mathrm{~kg} \mathrm{ha}^{-1}, 6630 \mathrm{~kg} \mathrm{ha}^{-1}$ yield, respectively).

\section{CONCLUSIONS}

In draughty cropyear the maximum yield increase caused by irrigation was $4270 \mathrm{~kg} \mathrm{ha}^{-1}$ (monoculture), 3264 $\mathrm{kg} \mathrm{ha}^{-1}$ (biculture) and $2681 \mathrm{~kg} \mathrm{ha}^{-1}$ (triculture). In dry cropyear there was strong interaction between water and nutrient supply. The yield surpluses of maize were significantly lower in the control treatment $(1436-2525 \mathrm{~kg}$ $\left.\mathrm{ha}^{-1}\right)$ than in the optimal NPK treatment $\left(2681-4270 \mathrm{~kg} \mathrm{ha}^{-1}\right)$. The yield increasing effect of fertilization was primarily influenced by the cropyear and modified by crop rotation and irrigation. In dry cropyear the yield increase over the control was $1282-1631 \mathrm{~kg} \mathrm{ha}^{-1}$ (non-irrigated) and $2527-3376 \mathrm{~kg} \mathrm{ha}^{-1}$ (irrigated). In favourable year the yield increase was highest in monoculture $\left(4633-4899 \mathrm{~kg} \mathrm{ha}^{-1}\right)$ but it was high in biculture (1838-2524 $\mathrm{kg} \mathrm{ha}^{-1}$ ) and in triculture (2696-3306 $\mathrm{kg} \mathrm{ha}^{-1}$ ) as well, respectively.

The cropyear, as abiotic stress modified the optimum fertilizer dose of maize grown in different crop rotation systems. In dry years lower fertilizer doses $\left(\mathrm{N}_{120-180}+\mathrm{PK}\right.$ [mono], $\mathrm{N}_{180}+\mathrm{PK}$ [bi], $\mathrm{N}_{60-180}+\mathrm{PK}$ [tri]) proved to be more efficient than in humid years $\left(\mathrm{N}_{180}+\mathrm{PK} ; \mathrm{N}_{180}+\mathrm{PK} ; \mathrm{N}_{120-180}+\mathrm{PK}\right)$, respectively. The scientific results of our long-term experiments proved that applying appropriate agrotechnical elements the abiotic stress effects caused by weather can be moderated but cannot be eliminated. In the dry cropyear of 2007 the maximum yield of maize with optimal fertilizer dose and irrigation was $8586-10970 \mathrm{~kg} \mathrm{ha}^{-1}$, while in favourable cropyear (2008) it ranged between 13729-14180 $\mathrm{kg} \mathrm{ha}^{-1}$. With the optimal application of agrotechical factors the yield loss caused by abiotic stress was 2-3 $\mathrm{t} \mathrm{ha}^{-1}$ on chernozem soil.

\section{REFERENCES}

Berzsenyi Z:: 1993. Növényanalízis a kukoricatermesztési kutatásokban. Akadémiai doktori értekezés tézisei, Martonvásár.

Győrffy B.: 1976. A kukorica termésére ható növénytermesztési tényezők értékelése. Agrártudományi Közlemények, 35. $239-266$.

Izsáki Z.: 2007. N and P impact on the yield of maize in a long-term trial. Cereal Research Communications, 35, 4. 1701-1711.

Kovačević, V. - Rastija, M. - Rastija, D. - Josipović, M. - Šeput, M.: 2006. Response of Maize to Fertilization with KCl on Gleysol of Sava Valley Area. Cereal Research Communications, 34. 2-3. 1129.

Liang B.C. - MacKenzieA.F.: 1994. Corn yield, nitrogen uptake and nitrogen use efficiency as influenced by nitrogen fertilization. Canadian Journal of Soil Science, 74. 2. 235-240.

Nagy J.: 1996. Effects of tillage, fertilization, plant density and irrigation on maize (Zea mays L.) yields. Acta Agronomica Hungarica 196, 2-3. 189-202.

Pepó P.: 2001. A genotípus és a vetésváltás szerepe a kukorica tápanyagellátásában csernozjom talajon. Növénytermelés, 50. 2-3. 189202.

Pepó P.-Vad A.-Berényi S.: 2006. Effect of some agrotechnical elements ont he yield of maiza on chernozem soil.-Cereal Research Communications. 34. 1.621-624.

Pepó P. - Zsombik L. - Vad A. - Berényi S. - Dóka L.: 2007. Agroecological and management factors with impact on the yield and yield stability of maize (Zea mays L.) in different crop rotation. Analele Universitatii Oradea, Facultatea de Protectia Mediului, Vol. 13. 181-187.

Pepó P. - Vad A. - Berényi S.: 2008. Effects of irrigation on yields of maize (Zea mays L.) in different crop rotation. Cereal Research Communication. 36. 3. 735-738.

Ruzsányi L.: 1990. A növények elővetemény-hatásának értékelése vízháztartási szempontból. Növénytermelés, 40. 1. 71-77.

Sárvári M.: 1995. A kukorica hibridek termőképessége és trágyareakciója réti talajon. Növénytermelés. 44. 2. 179-191.

Sárvári M. - Szabó P.: 1998. A termesztési tényezők hatása a kukorica termésére. Növénytermelés, 47. 2. $213-221$. 